\title{
Karakteristik Briket Bioarang dari Campuran Limbah Baglog Jamur Tiram (Pleurotus ostreatus) dan Sekam Padi
}

\author{
Fatwa Aji Kurniawan* dan Ahmad Aftah Syukron \\ Program Studi Fisika Universitas Ma'arif Nahdlatul Ulama Kebumen \\ Jalan Kusuma No. 45 Kebumen Jawa Tengah \\ *fatwaphysics@gmail.com
}

ABSTRACT

\begin{abstract}
The energy diversification policy issued by the Government of Indonesia requires people to find fuels other than fossils. This research aims to produce briquettes from good quality charcoal mixtures of oyster mushroom baglog (JT) and rice husk (SK) wastes so that it can be used as an alternative fuel. This research was carried out in three stages, namely charcoal making or carbonization, briquette making and quality testing. The variables used in this research are the mixture compositions of JT and SK. The mixture composition used of 100\% JT: 0\% SK for sample A, 75\% JT: $25 \%$ SK for sample B, 50\% JT: $50 \%$ SK for sample C, $25 \%$ JT: $75 \%$ SK for sample D and 0\% JT: $100 \%$ SK for sample E. The results of this research were obtained the most optimal mixture to produce good quality briquettes with the composition of 25\% JT: $75 \%$ SK (sample D) where the calorific value generated of 3541 calorie/gr, $1.57 \%$ moisture content and $36.20 \%$ ash content.
\end{abstract}

Keywords: Briquettes, Alternative energy, Oyster Mushroom, Rice Husk

\section{ABSTRAK}

Kebijakan diversifikasi energi yang dikeluarkan Pemerintah Indonesia menuntut masyarakat untuk menemukan bahan bakar selain fosil. Penelitian ini bertujuan untuk menghasilkan briket dari campuran arang limbah baglog jamur tiram (JT) dan arang sekam padi (SK) yang berkualitas sehingga dapat digunakan sebagai bahan bakar alternatif. Penelitian ini secara garis besar dilakukan dalam tiga tahap yaitu pengarangan atau karbonisasi, pembriketan dan pengujian kualitas briket. Variabel yang digunakan dalam penelitian ini adalah komposisi campuran JT dan SK. Komposisi campuran yang digunakan yaitu 100\% JT:0\% SK untuk sampel A, 75\% JT:25\% SK untuk sampel B, 50\% JT:50\% SK untuk sampel C, 25\% JT:75\% SK untuk sampel D dan 0\% JT:100\% SK untuk sampel E. Dari hasil penelitian disimpulkan bahwa campuran yang paling optimal untuk mendapatkan briket berkualitas baik yaitu dengan komposisi 50\% arang limbah baglog jamur tiram : 50\% arang sekam padi dimana diperoleh nilai kalor sebesar $3541 \mathrm{kal} / \mathrm{gr}$, kadar air $1.57 \%$ dan kadar abu 36.20\%.

Kata Kunci: Briket, Energi Alternatif, Jamur Tiram, Sekam Padi

\section{PENDAHULUAN}

Konsumsi dan kebutuhan minyak bumi di Indonesia sekarang ini semakin meningkat seiring dengan meningkatnya pemakaian energi untuk keperluan industri, transportasi dan rumah tangga. Untuk mengatasi permasalahan tersebut, pemerintah telah membuat kebijakan berupa diversifikasi energi dengan tujuan untuk mengurangi ketergantungan terhadap minyak dan gas bumi ${ }^{[1]}$. Salah satu di antaranya adalah dengan mengurangi konsumsi minyak bumi dari 54\% pada tahun 2005 menjadi $20 \%$ pada tahun $2025^{[2]}$. Berkaitan dengan kebijakan diversifikasi energi, maka perlu dilakukan pencarian, pembuatan dan pengembangan energi alternatif yang efektif, efisien dan murah sehingga dapat digunakan oleh masyarakat dari berbagai kalangan.

Budidaya jamur di Indonesia mengalami perkembangan yang sangat pesat. Menurut data Direktorat Jenderal Holtikultura (2013), luas lahan budidaya jamur di Indonesia 584 ha dengan rata-rata hasil produksi mengalami kenaikan $9 \%$ menjadi 76,28 ton/ha pada tahun 
$2013^{[3]}$. Salah satu jenis jamur yang mengalami peningkatan produksi yaitu jamur tiram (Pleuratus Ostreatus).

Tidak dapat dipungkiri bahwa tingginya produksi jamur tiram menyebabkan permasalahan baru berupa limbah baglog media tumbuh jamur tiram. Dari hasil pengamatan yang dilakukan memberikan informasi bahwa limbah baglog jamur tiram dibuang ke sungai dan di kebun sehingga berpotensi mencemari lingkungan. Sebagian pembudidaya sudah berusaha memanfaatkan limbah tersebut untuk pertanian tetapi hasilnya tidak memuaskan karena menyebabkan tanaman terkena hama ulat.

Bahan baku baglog jamur tiram yaitu serbuk kayu karena mengandung selulosa dan lignin yang cukup banyak ${ }^{[4]}$. Berdasarkan penelitian yang telah dilakukan serbuk kayu dapat digunakan sebagai bahan baku pembuatan briket ${ }^{[5]}$. Pemanfaatan limbah baglog jamur tiram untuk bahan baku briket telah dilakukan dan diketahui bahwa nilai kalor briket yang dihasilkan sebesar $3306 \mathrm{kal} / \mathrm{gr}$ pada tekanan kempa pencetakan $100 \mathrm{~kg} / \mathrm{cm}^{2}{ }^{[6]}$.

Nilai kalor suatu briket dapat ditingkatkan dengan menambahkan bahan campuran lain yang memiliki nilai kalor lebih tinggi ${ }^{[5]}$. Briket arang serbuk gergaji kayu meranti yang awalnya memiliki nilai kalor $6001 \mathrm{kal} / \mathrm{gr}$ dapat ditingkatkan menjadi $6109 \mathrm{kal} / \mathrm{gr}$ dengan menambahkan $20 \%$ arang kayu galam.

Produksi gabah kering Indonesia pada tahun 2015 menurut perhitungan sebesar 75.55 juta ton atau mengalami kenaikan sebanyak 4.70 juta ton (6.64 persen) dibandingkan tahun 2014. Kenaikan produksi padi tahun 2015 diperkirakan terjadi di Pulau Jawa sebanyak 1.83 juta ton dan di luar Pulau Jawa sebanyak 2,88 juta ton ${ }^{[7]}$. Keadaan tersebut pastinya akan diikuti dengan bertambahnya limbah padi berupa sekam. Adapun total potensi sekam padi di Indonesia sendiri sebesar 13 juta ton per tahun ${ }^{[8]}$.

Pemanfaatan sekam padi sebagai bahan baku briket sudah banyak dilakukan oleh masyarakat. Beberapa penelitian yang telah dilakukan menyebutkan bahwa briket sekam padi memiliki nilai kalor yang tinggi yaitu pada kisaran $4128-4324 \mathrm{kal} / \mathrm{gr}^{[9,10]}$.

Pembuatan briket dengan bahan baku campuran arang limbah baglog jamur tiram dan sekam padi perlu dilakukan. Hal ini bertujuan untuk mengetahui pengaruh penambahan arang sekam padi terhadap kualitas briket limbah baglog jamur tiram.

\section{METODE}

Bahan penelitian yang digunakan terdiri dari limbah baglog jamur tiram, sekam padi, dan tepung kanji sebagai perekat. Limbah baglog jamur tiram dan sekam padi yang telah dikarbonisasi kemudian dihaluskan dan diayak menggunakan ayakan mesh $40(0.33 \mathrm{~mm})$ untuk menghasilkan serbuk arang yang halus dan merata. Kedua serbuk arang tersebut kemudian dicampurkan dengan komposisi seperti disajikan pada Tabel 1.

Tabel 1. Persentase Komposisi Bahan Tiap Sampel Briket

\begin{tabular}{ccc}
\hline Sampel & $\begin{array}{c}\text { Persentase Serbuk Arang } \\
\text { Limbah Baglog Jamur Tiram }\end{array}$ & $\begin{array}{c}\text { Persentase Serbuk Arang } \\
\text { Limbah Sekam Padi }\end{array}$ \\
\hline A & $100 \%$ & $0 \%$ \\
B & $75 \%$ & $25 \%$ \\
C & $50 \%$ & $50 \%$ \\
D & $25 \%$ & $75 \%$ \\
E & $0 \%$ & $100 \%$ \\
\hline
\end{tabular}


Tepung kanji dan air masing-masing sebanyak 10\% dari massa bahan dicampurkan kemudian diaduk sampai merata. Adonan briket kemudian dicetak berbentuk silinder berdiameter $4 \mathrm{~cm}$ dan tinggi $5 \mathrm{~cm}$ dengan tekanan kompaksi $100 \mathrm{~kg} / \mathrm{cm}^{2}$. Briket yang telah dicetak kemudian dikeringkan untuk mengurangi kadar air terkandung. Karakterisasi briket dilakukan untuk mengetahui kualitas fisika dari briket tersebut. Kualitas fisika briket yang dimaksud adalah nilai kalor, kadar air dan kadar abu. Nilai kalor, kadar air dan kadar abu briket masing-masing diukur menggunakan boom calorimeter.

Diagram alir proses penelitian secara garis besar dapat dilihat pada Gambar 1.

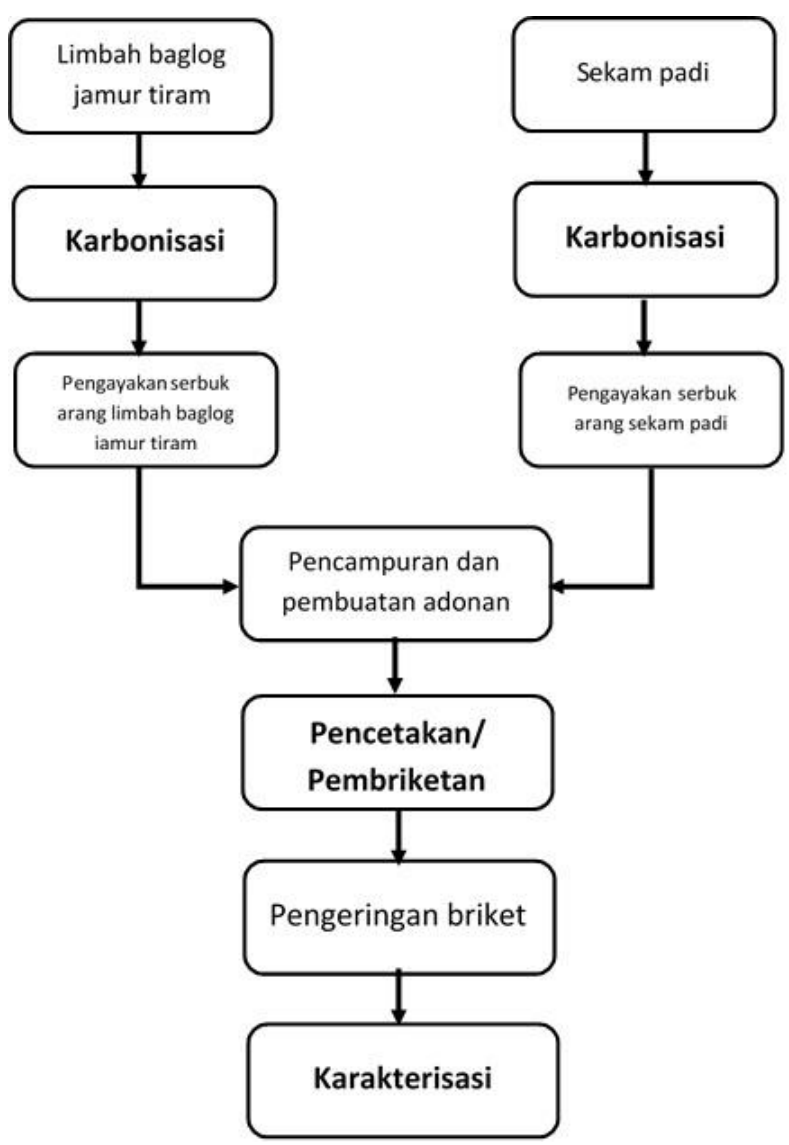

Gambar 1. Diagram Alir Proses Penelitian

\section{HASIL DAN PEMBAHASAN}

Penelitian ini dilakukan dengan menggunakan variasi komposisi bahan penyusun briket. Bahan penyusun briket yang digunakan adalah arang limbah baglog jamur tiram dan arang sekam padi. Dari pengujian sifat fisik yang telah dilakukan di Laboratorium Ilmu Bahan Makanan Ternak (IBMT) Universitas Jenderal Soedirman Purwokerto, dapat diketahui sifat fisik briket campuran arang limbah baglog jamur tiram dan arang sekam padi. Hasil uji sifat fisik briket tersebut dapat dilihat pada Tabel 2. Sifat fisik yang mempengaruhi kualitas briket antara lain kadar air, kadar abu, dan nilai kalor ${ }^{[11,12]}$. 
Tabel 2. Sifat Fisik Briket Campuran Arang Limbah Baglog Jamur Tiram dan Arang Sekam Padi

\begin{tabular}{cccc}
\hline Sampel & $\begin{array}{c}\text { Kadar Air } \\
(\%)\end{array}$ & $\begin{array}{c}\text { Kadar Abu } \\
(\%)\end{array}$ & Nilai Kalor (kal/gr) \\
\hline A & 1.74 & 44.9 & 3003.3 \\
B & 1.61 & 41.4 & 3077.4 \\
C & 1.57 & 36.1 & 3547.1 \\
D & 1.58 & 39.0 & 3298.1 \\
E & 1.80 & 32.0 & 3361.0 \\
\hline
\end{tabular}

\section{Kadar Air}

Kadar air diukur dengan tujuan untuk mengetahui kandungan air yang terdapat pada briket setelah dikeringkan. Pengeringan briket dilakukan dengan menjemur briket selama 4 hari mulai pukul 09.00 WIB sampai dengan 14.00 WIB. Pada jam tersebut teramati suhu pengeringan rata-rata sebesar $38^{\circ} \mathrm{C}$.

Hasil penelitian menunjukkan kadar air paling kecil terdapat pada sampel $\mathrm{C}$ dengan komposisi arang limbah baglog jamur tiram dan arang sekam padi masing-masing $50 \%$. Berdasarkan Tabel 2 dan Gambar 3, besarnya kadar air yang terdapat pada sampel C yaitu $1.57 \%$. Walaupun demikian, nilai tersebut tidak berbeda jauh dengan kadar air pada sampel A, B, D dan E.

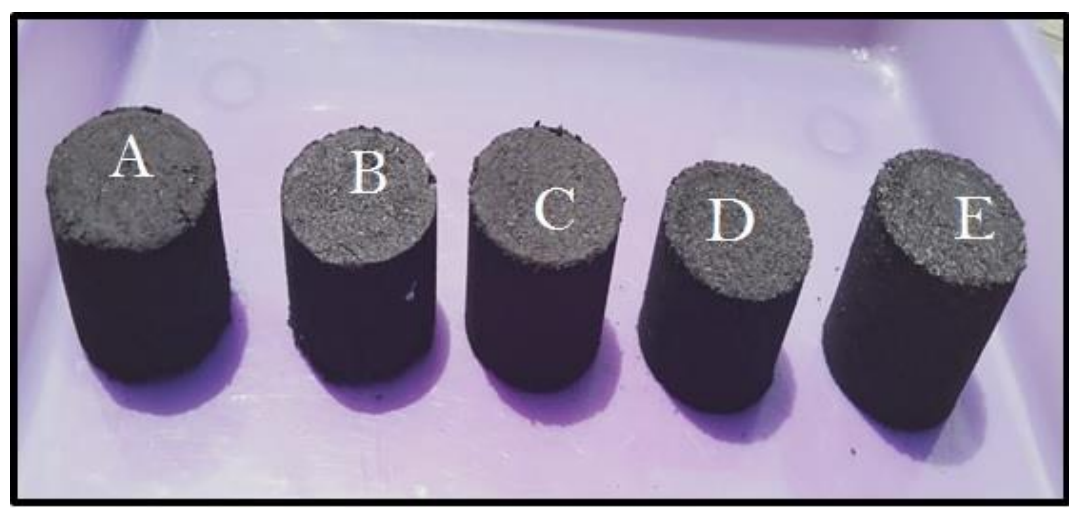

Gambar 2. Sampel Briket Bioarang Setelah Dikeringkan

Kadar air pada briket dipengaruhi oleh beberapa faktor diantaranya suhu karbonisasi, lama karbonisasi dan suhu pengeringan. Semakin lama waktu karbonisasi maka kadar air akan semakin rendah ${ }^{[13]}$ dan semakin tinggi suhu karbonisasi akan membuat kadar air pada briket semakin kecil ${ }^{[14]}$. Karbonisasi menyebabkan pori-pori pada sekam padi dan baglog limbah jamur tiram semakin terbuka. Pori-pori yang terbuka tersebut menyebabkan air mudah terlepas sehingga ketika briket dikeringkan air akan menguap lebih banyak. Begitu juga dengan suhu pengeringan, semakin tinggi suhu pengeringan briket akan menyebabkan semakin banyak air yang hilang sehingga kadar air dalam briket yang dihasilkan semakin berkurang ${ }^{[8]}$. 


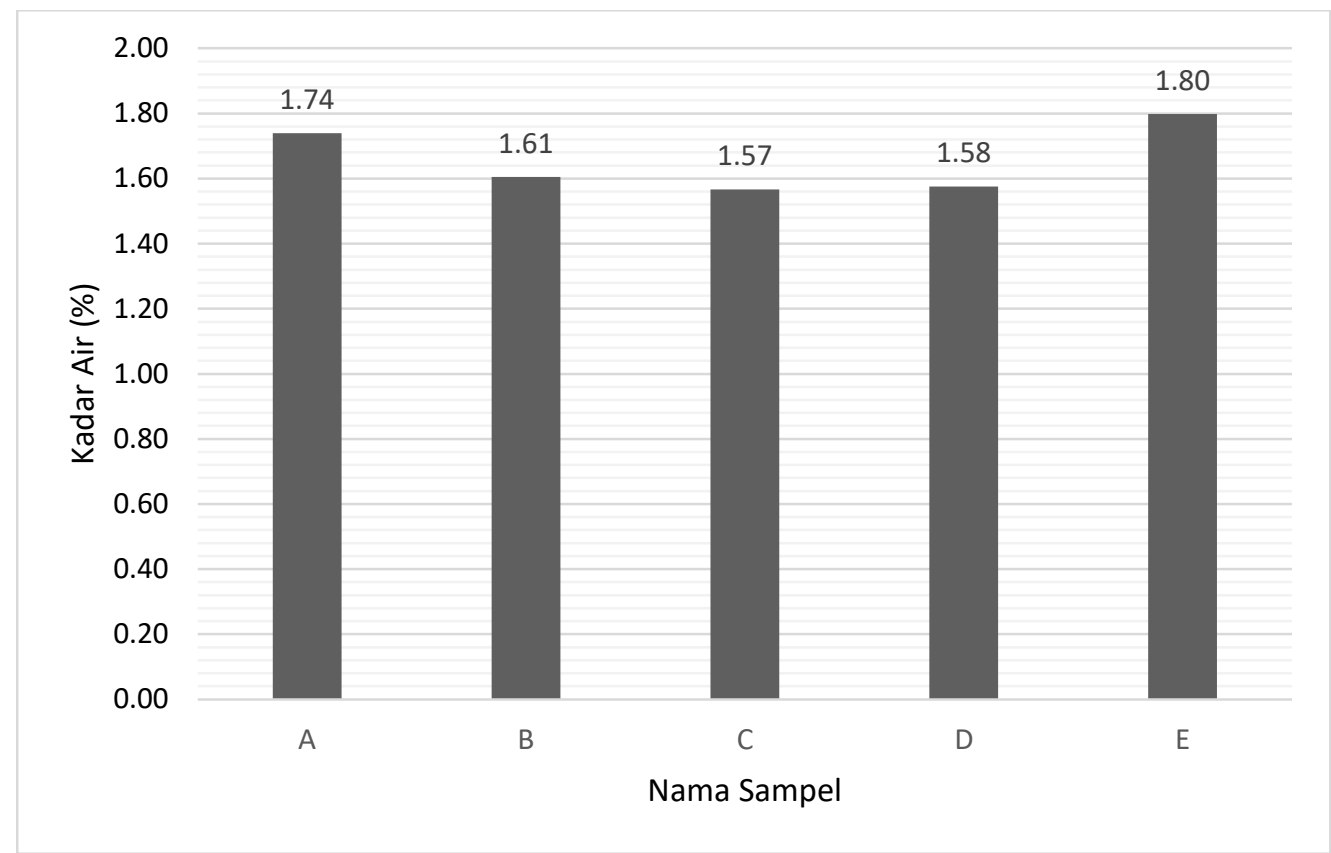

Gambar 3. Persentase Kadar Air tiap Sampel

\section{Kadar Abu}

Kadar abu merupakan residu atau sisa pembakaran yang sudah tidak memiliki nilai kalor karena tidak memiliki unsur karbon. Besarnya kadar abu pada briket sebanding dengan kandungan unsur-unsur anorganik yang terdapat pada briket tersebut ${ }^{[15]}$. Unsur-unsur yang terkandung dalam abu antara lain silika, kalsium dan magnesium ${ }^{[16]}$. Tujuan pengukuran kadar abu adalah untuk mengetahui besarnya kandungan abu dari bahan penyusun briket.

Hasil analisis menunjukkan kadar abu paling besar terdapat pada sampel A yaitu $44.9 \%$ dan kadar abu paling kecil terdapat pada sampel E yaitu 32.0\% seperti disajikan pada Gambar 4. Komposisi briket pada sampel A adalah $100 \%$ arang limbah baglog tiram. Besarnya kadar abu pada sampel A disebabkan oleh adanya unsur kalsium karbonat $\left(\mathrm{CaCO}_{3}\right)$ yang terdapat pada limbah baglog jamur tiram. Kalsium karbonat merupakan bahan anorganik yang tidak dapat terurai pada proses pembakaran.

Selain faktor unsur anorganik pada bahan penyusun briket, besarnya kadar abu juga dipengaruhi oleh suhu pengeringan briket. Kadar abu akan semakin menurun dengan semakin tingginya suhu pengeringan karena berkaitan dengan kadar air pada briket. Suhu pengeringan yang semakin tinggi menyebabkan kadar air menurun sehingga kadar abu yang dihasilkan rendah ${ }^{[17]}$. Kadar abu juga dipengaruhi oleh suhu karbonisasi, semakin tinggi suhu karbonisasi maka kadar abu akan semakin besar. Hal ini diakibatkan oleh bahan banyak yang terdekomposisi menjadi abu ${ }^{[14]}$. 


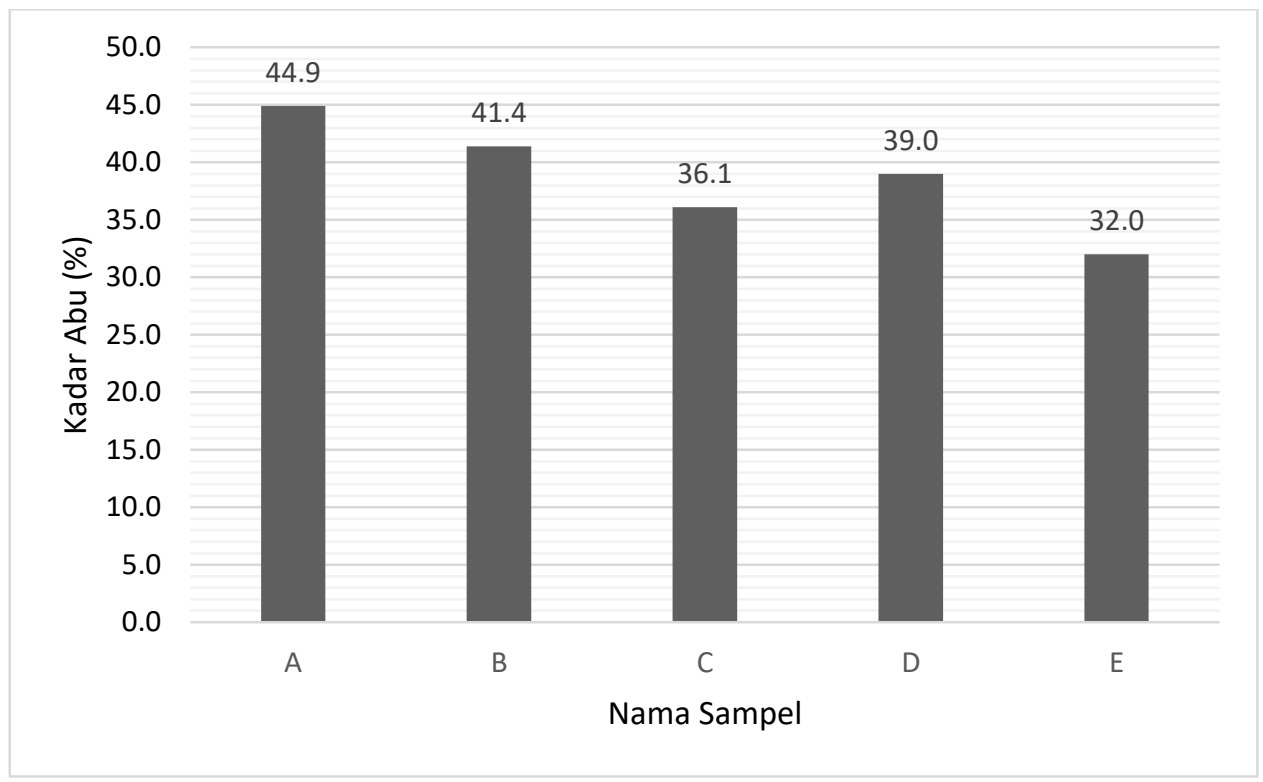

Gambar 4. Persentase Kadar Abu Tiap Sampel

\section{Nilai Kalor}

Nilai kalor merupakan parameter utama yang menunjukkan kualitas briket arang. Nilai kalor berhubungan dengan energi panas yang dapat dihasilkan briket pada proses pembakaran. Semakin tinggi nilai kalor briket akan menghasilkan energi panas yang tinggi pula. Berdasarkan data hasil analisa pada masing-masing sampel diperoleh nilai kalor briket yang bervariasi seperti disajikan pada Gambar 5.

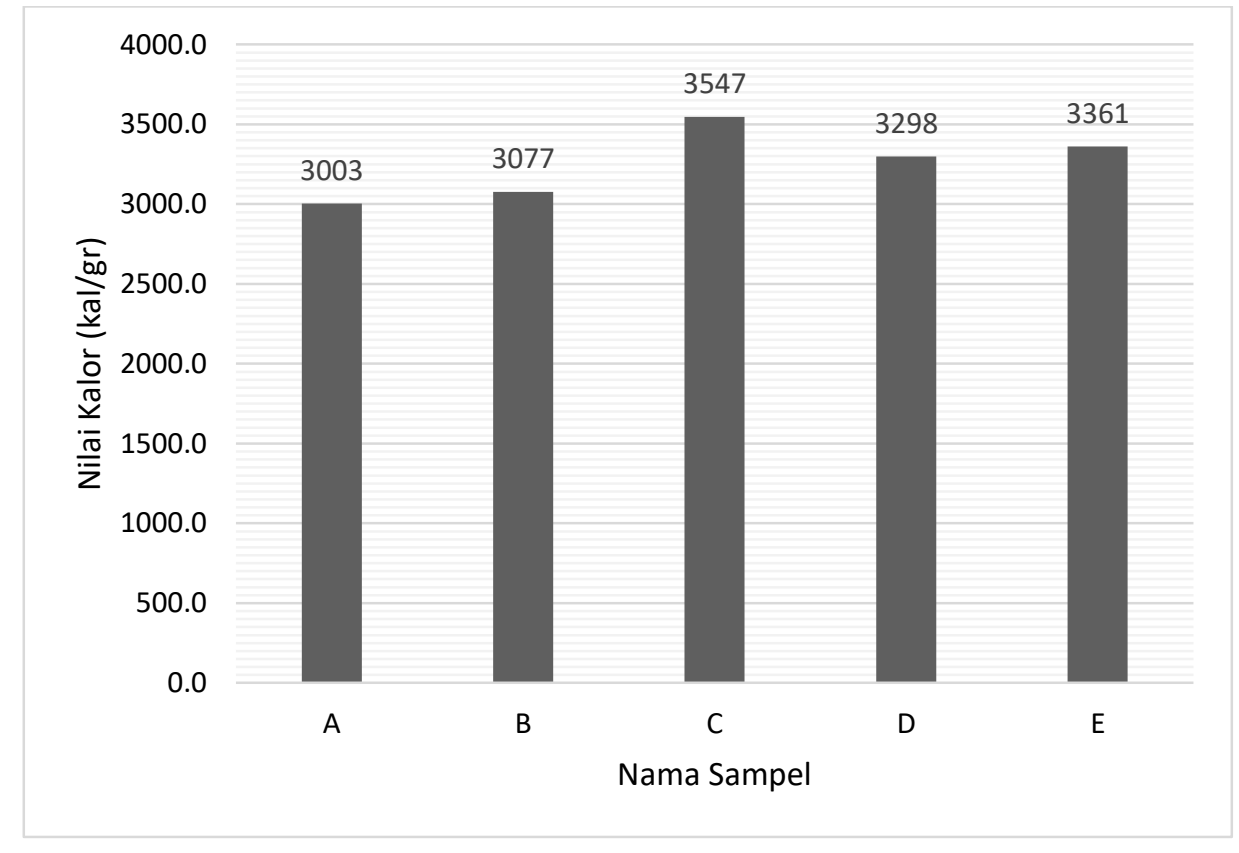

Gambar 5. Nilai Kalor Tiap Sampel

Gambar 5 menunjukkan nilai kalor tertinggi dihasilkan oleh briket pada sampel $\mathrm{C}$ dengan komposisi arang limbah baglog jamur tiram dan sekam padi masing-masing 50\%. Nilai kalor pada komposisi tersebut mencapai $3547 \mathrm{kal} / \mathrm{gr}$. Tingginya nilai kalor pada sampel C dipengaruhi oleh rendahnya kadar air dan kadar abu jika dibandingkan dengan sampel yang lain. Nilai kalor briket ini lebih tinggi daripada hasil penelitian yang dilakukan oleh Dharma 
(2013) yang hanya menghasilkan nilai kalor $3306 \mathrm{kal} / \mathrm{gr}$. Hasil tersebut menunjukkan bahwa penambahan bahan baku sekam padi dapat menaikkan nilai kalor briket. Walaupun demikian nilai kalor tersebut masih berada di bawah Standar Nasional Indonesia yaitu minimal 5000 $\mathrm{kal} / \mathrm{gr}^{[17]}$.

Rendahnya nilai kalor briket arang tersebut disebabkan oleh kandungan kadar abu yang dihasilkan oleh briket sangat tinggi yaitu $32.0 \%-36.1 \%$. Kandungan tersebut jauh lebih tinggi dari Standar Nasional Indonesia yaitu maksimal $8 \%$. Nilai kalor yang dihasilkan cenderung menurun dengan semakin meningkatnya kadar abu seperti ditunjukkan Gambar 6. Hasil tersebut diperkuat oleh penelitian Fizal dkk (2018) bahwa semakin tinggi kadar abu suatu briket menyebabkan semakin rendahnya nilai kalor yang dihasilkan ${ }^{[14]}$. Tingginya kadar abu briket tersebut dipengaruhi oleh banyaknya kandungan kalsium karbonat pada limbah baglog jamur tiram yang tidak terkarbonisasi secara sempurna. Selain itu kandungan selulosa limbah baglog jamur tiram sudah terdeformasi terlebih dahulu oleh jamur tiram sehingga pada proses pengarangan dengan suhu tinggi akan cepat menjadi abu.

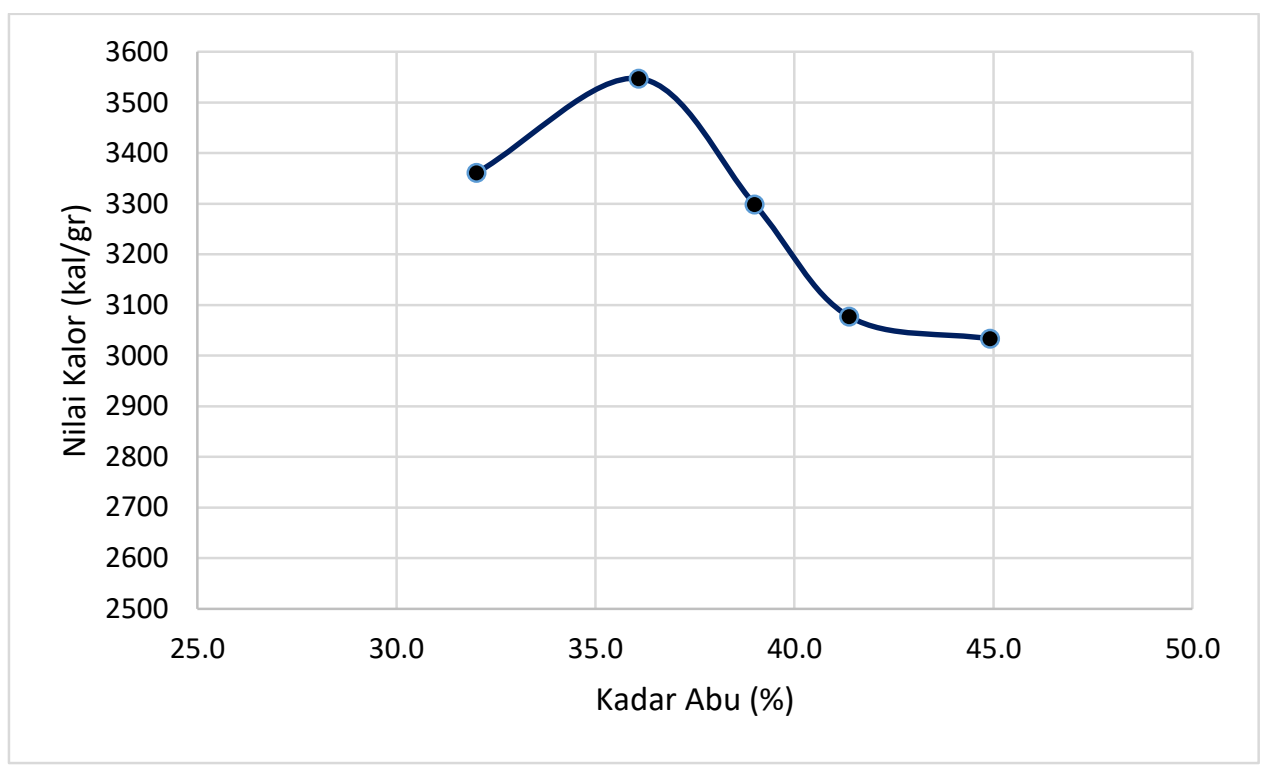

Gambar 6. Hubungan antara Kadar Air dan Nilai Kalor

\section{KESIMPULAN}

Arang limbah baglog jamur tiram dapat digunakan sebagai bahan baku briket. Penambahan arang sekam padi berpengaruh pada nilai kalor yang dihasilkan. Briket terbaik yang dapat dihasilkan mengandung kadar air $1.57 \%$, kadar abu $36.1 \%$ dan nilai kalor $3547 \mathrm{kal} / \mathrm{gr}$ pada komposisi arang limbah baglog jamur tiram dan sekam padi masing-masing 50\%.

\section{UCAPAN TERIMA KASIH}

Terima kasih kami ucapkan kepada DRPM KEMENRISTEK-DIKTI yang telah memberikan dana berupa hibah penelitian pada tahun 2019 . 


\section{DAFTAR PUSTAKA}

1 Azmi, R., \& Amir, H. 2014. Ketahanan Energi: Konsep, Kebijakan dan Tantangan bagi Indonesia. Badan Kebijakan fiskal kementerian Keuangan

2 Hutagulung, A. M., Yunita, W., Rahamri, N. C., \& Johansyah, A. 2015. Rencana Strategis 2015-2019 Kementerian Energi dan Sumber Daya Mineral. Direktorat Jenderal Miny. dan Gas Bumi

3 Bahar, N. C. 2014. Statistik Produksi Hortikultura Tahun 2013. Direktorat Jenderal Hortik

4 Ginting, A. R., Herlina, N. H., \& Tyasmoro, S. Y. 2013. Studi PErtumbuhan dan Produksi Jamur Tiram Putih (Pleorotus ostreatus) pada Media Tumbuh Gergaji Kayu Sengon dan Bagas Tebu. J. Produksi Tanam, 1(2), 17-24

5 Yuniarti, Y. P., Theo, Y., Faizal., \& Arhamsyah, 2011. Briket Arang dari Serbuk GErgajian Kayu Meranti dan Kayu Galam. J. Ris. Ind. Has. Hutan, 3(2), 38-43

6 Dharma, U. S. 2013. Pemanfaatan Biomassa Limbah Jamur Tiram Sebagai Bahan Bakar Alternatif Untuk Proses Sterilisasi Jamur Tiram. TURBO, 2(2), 18-22

7 Statistik, B. P. 2015. Produksi Padi, Jagung, dan Kedelai. 2014. Jakarta (ID): Badan Pusat Statistik

8 Tarsito, T., Sutanto, H., \& Mahendrajaya. 2013. Pengaruh Variasi Komposisi Briket Organik Terhadap Temperatur Dan Waktu Pembakaran. Berk. Fis, 16(1), 21-26

9 Qistina, I., Sukandar, D., \& Trilaksono, T. 2016. Kajian Kualitas Briket Biomassa dari Sekam Padi dan Tempurung Kelapa, J. Kim. Val, 2(2), 136-142

10 Faizal, M., Saputra, M., \& Zainal, F. A. 2015. Pembuatan Briket Bioarang dari Campuran Batubara dan Biomassa Sekam Padi dan Enceng Gondok. J. Tek. Kim, 21(4), 27-38

11 Mangalla, L. K., Kadir, A., \& Kadir. 2019. Biobriket Karbonisasi Dari Cangkang Mete Dan Sekam Padi Untuk Energi Berkelanjutan. Din. J. Ilm. Tek. Mesin, 10(2), 1-6

12 Mariki. W. W., \& Nugraha, A. 2018. Pengaruh Persentase Briket Campuran Gambut dan Arang Pelepah Daun Kelapa Sawit terhadap Sifat Fisik Briket. Prosiding SNRT (Seminar Nasional Riset Terapan), 1-11

13 Siahaan, A., Hutapea, M., \& Hasibuan, R. 2013. Penentuan Kondisi Optimum Suhu Dan Waktu Karbonisasi. J. Tek. Kim. USU, 2(1), 26-30

14 Faizal, M., Rifky, A. D., \& Sanjaya, I. 2018. Pembuatan Briket dari Campuran Limbah Plastik LDPE dan Kulit Buah Kapuk Sebagai Energi Alternatif. J. Tek. Kim, 24(1), pp. $8-16$

15 Wicaksono, W. R., \& Nurhatika, S. 2018. Variasi Komposisi Bahan pada Pembuatan Briket Cangkang Kelapa Sawit (Elaeis guineensis) dan Limbah Biji Kelor (Moringa oleifera). J. Sains dan Seni ITS, 7(2), 66-70

16 Manuahe, R., Sumajouw, M. D. J., \& Windah, R. S. 2014. Kuat Tekan Beton Geopolymer Berbahan Dasar Abu Terbang. J. Sipil Statik, 2(6), 277-282

17 Suharto, B., Sutanhaji, A. T., \& Sunarsih. 2016. Uji Kualitas Briket Kotoran Sapi Pada Variasi Kadar Perekat Tapioka dan Suhu Pengeringan. J. Sumberd. Alam dan Lingkung., $3(2), 38-43$ 